\title{
PELATIHAN KESENIAN REBANA GRUP AL-MAGHFIROH DI CIKAMBUY DESA SANGKANHURIP KECAMATAN KATAPANG KABUPATEN BANDUNG
}

\author{
Mochammad Septa Satria Saputra \\ Program Magister Tatakelola Seni \\ Institut Seni Indonesia Yogyakarta \\ Email : kakangseptass95@gmail.com
}

Diterima : 21 April 2020. Disetujui : 30 Mei 2020. Dipublikasikan : 10 Juni 2020

(C2020 - DESKOVI Universitas Maarif Hasyim Latif. Ini adalah artikel dengan akses terbuka di bawah lisensi CC BY 4.0 (https://creativecommons.org/licenses/by/4.0/)

\begin{abstract}
ABSTRAK
Penelitian ini berjudul "pelatihan kesenian rebana grup Al-Maghfiroh di Cikambuy Desa Sangkanhurip Kecamatan Katapang Kabupaten Bandung”. Penelitian ini didasari oleh alasan dari grup kesenian rebana yang aktif di Cikambuy Kabupaten Bandung. Grup Al-Maghfiroh berbeda dengan grup kesenian rebana lainnya, grup ini digerakan oleh Pak Toni dan oleh murid-muridnya dan sering mengikuti kegiatan-kegiatan yang bernuansa Islami khususnya didaerah Cikambuy dan sekitarnya. Dengan bimbingan pelatih, murid mampu memainkan alat musik kesenian rebana secara bersama-sama, bergembira, serta mempunyai daya tarik tersendiri. Pada kegiatan latihan kesenian rebana, murid mendapat motivasi dari pelatih dan mendapat dukungan dari orang tua murid. Berdasarkan observasi kebeberapa tempat didaerah Cikambuy, Grup AlMaghfiroh ini lebih cenderung menarik sehingga proses latihannya dilakukan dengan jadwal yang telah ditentukan tiap minggunya. Ini yang menjadi kajian penelitian saya, melihat dan mengamati proses pelatihan untuk diteliti dikediaman Pak Toni. Pelatihan kesenian rebana grup Al-Maghfiroh Kecamatan Katapang Kabupaten Bandung, dengan tujuan untuk memberikan gambaran tentang proses pelatihan kesenian rebana yang dilakukan di Cikambuy Kabupaten Bandung secara sistematis, faktual, serta aktual mengenai objek yang akan dikaji. Sedangkan teknik pengumpulan data yaitu melalui observasi, wawancara, dokumentasi, serta studi literarul. Berdasarkan hasil penelitian menunjukan bahwa murid dapat lebih terampil dalam memainkan alat musik kesenian rabana, cara pelatihan yang dipakai oleh Pak Toni yaitu dengan cara di beo sangat membantu dalam hal menyampaikan materi kepada murid, dan adanya ketergantungan yang timbul dari murid dalam proses pelatihan sehingga terjadinya ketidak seriusan dalam pelatihan kesenian rebana.
\end{abstract}

Kata Kunci : Pelatihan, Kesenian, Rebana

\begin{abstract}
This research entitled "training of art of tambourine group Al-Maghfiroh in Cikambuy Village Sangkanhurip District Katapang District Bandung". This research is based on the reason of grup of tambourine art that active in Cikambuy Regency Bandung. Group Al-Maghfiroh is different from other groups of tambourine art, this groups is driven by Mr.Toni and by his students and often follow the activities of Islamic nuance especially in Cikambuy and surrounding areas. With the coach's guidance, students are able to play the tambourine art instrumen together, have fun, and have their own charms. In the rehearsal art training activities, students get motivation from the trainer and get support from the parents of the students. Based on observations to some places in Cikambuy area, this Al-Maghfiroh Group is more likely to attract so that the training process is done with the coach and his peers. This is the study of my research, looking at and observing the training process to be studied in Mr. Toni's residence. Training of tambourine art group Al-Maghfiroh District Katapang Bandung Regency, with the aim to provide an overview of the art training process conducted Cikambuy Bandung regency as well as about the object to be studied. While the technique of data collection is through observation, interview, documentation, and literatur study. Based on the result of research shows that students can be more skilled in playing musical instruments rebana, the way of training used by Mr. Toni is by way of parrots very helpful in terms of delivering material to students, and the dependence arising from students in the training process so that the occurrence art training.
\end{abstract}

Keywords : Training, Art, Rebana 


\section{PENDAHULUAN}

Kesenian merupakan bagian dari kebudayaan, merupakan warisan nenek moyang bangsa Indonesia yang telah ada dan diwariskan sejak turun temurun. Keberadaan kesenian perlu mendapatkan pembinaan dan pemeliharaan kemudian dikembangkan serta dipertahankan kelestariannya. Hal tersebut dilakukan agar kesenian tidak mengalami kepunahan. Salah satu upaya untuk mempertahankan dan mengembangkan seni yang terdapat di daerah, adalah dengan cara pelatihan kesenian pada suatu lembaga di sekolah maupun di luar sekolah. Salah satu kegiatan pelatihan yang dilakukan diluar sekolah , adalah pelatihan kesenian rebana di Cikambuy Desa Sangkanhurip Kecamatan Katapang Kabupaten Bandung. Dikatagorisasikan sebagai pendidikan luar sekolah, dikarenakan pembelajarannya dilakukan dalam bentuk pelatihan dengan jadwal yang tidak tetap. Jadwal latihan ditentukan berdasarkan kesepakatan antara pelatih dengan murid. Pelatihan tersebut dilakukan bukan untuk mencetak peserta pelatihan (murid atau masyarakat) menjadi seniman, tetapi lebih kepada pemberian pengalaman dan keterampilan. Sekali lagi tujuan pelatihan seni di sini bukanlah mempersiapkan diri menjadi seorang seniman, melainkan menumbuhkan ketertarikan dan motivasi peserta pelatihan, murid atau masyarakat luas agar tertarik mempelajari dan melestarikan kesenian Rebana dan memperoleh pengalaman dalam berkesenian, baik praktik maupun apresiasi.

Rebana adalah salah satu jenis musik tradisional yang banyak tersebar dan dapat ditemukan dengan mudah di tengah masyarakat Indonesia. Keberadaan alat musik rebana selalu dikaitkan dengan budaya Islam di kalangan masyarakat beragama Islam. Berdasarkan hasil studi kepustakaan yang dilakukan di beberapa tempat, diketahui bahwasannya secara historis, Seni Qasidah lahir bersamaan dengan kelahiran Islam. Untuk pertama kalinya, Qasidah ditampilkan oleh kaum Anshar (penolong Nabi Muhammad SAW dan sahabatsahabatnya dari kaum Muhajirin dalam perjalanan hijrah dari tanah kelahirannya (Makkah) ke Yastrib (Madinah). Pada saat itu beberapa kaum Anshar menyambut kedatangan Nabi dan mendengarkan lagu-lagu pujian diiringi dengan lantunan musik rebana. Lagu-lagu pujian saat itu pun melegenda hingga hari ini sebagai lagu klasik dan masih dapat dinikmati hingga sekarang.

Qasidah merupakan lagu atau nyanyian. Tetapi arti Qasidah selanjutnya menunjuk kepada lagu dan musik dengan ciri tersendiri, yaitu lagu dengan syair-syair bertemakan agama atau dakwah Islam. Instrumen yang digunakan dalam kesenian Qasidah adalah alat yang terbuat dari bahan baku kayu dan kulit berbentuk bulat, yaitu Rebana. Instrumen ini dimainkan dengan cara dipukul oleh telapak tangan sebelah kanan, sedangkan tangan sebelah kiri memegang instrumen yang akan dimainkan.

Cikambuy Desa Sangkanhurip merupakan suatu daerah yang terdapat di Kecamatan Katapang Kabupaten Bandung. Di daerah tersebut terdapat "Rumah Pelatih Kesenian Rebana" yang fungsinya dimanfaatkan untuk menimba ilmu agama untuk anak-anak. Rumah pelatih tersebut merupakan tempat yang menjadikan kesenian Rebana sebagai salah satu kegiatan yang dipelajari selain ilmu agama. Muridmurid yang mengikuti pelatihan Rebana ada 12 orang laki-laki dan 3 orang perempuan. Salah satu manfaat diselenggarakannya kegiatan tersebut di lingkungan sekitar Cikambuy Desa Sangkanhurip, adalah untuk membuat lingkungan menjadi nyaman, aman, karena adanya pendidikan untuk generasi penerus, menunjukan syiar Islam di daerah yang tantangannya banyak dan bermacam-macam.

Adapun prestasi yang sudah diraih oleh murid yang mengikuti pelatihan kesenian rebana khususnya dibidang agama yang selalu diadakan dilingkungan desa setempat adalah juara Kesenian Rebana, pernah tampil di acara muludan di daerah Cimonce Ciwidey, tampil di Cikambuy acara pernikahan di madrasah Asy-Syakur, tampil di acara Syukuran Khitanan di Kabupaten Bandung.

Tujuan lainnya dari kegiatan pelatihan Kesenian Rebana ini adalah agar Kesenian Rebana dapat dilestarikan supaya tidak punah, agar anak mengenal dan menyukai Kesenian Rebana, dengan dibiasakan cinta Rosul dengan melantunkan sholawat kepada Nabi yang diiringi dengan musik Rebana, dan murid diberikan pemahaman tentang bagaimana cara bermain alat musik yang terdapat dalam pelatihan Kesenian Rebana. Untuk pelaksanaan latihannya diadakan minimal tiga kali dalam satu minggu yaitu hari minggu malam, rabu malam, jum'at malam pukul 19.30-WIB, tempatnya adalah rumah pelatih di Cikambuy Desa Sangkanhurip Kecamatan Katapang Kabupaten Bandung.

Dalam pelatihan Kesenian Rebana, tentu memiliki materi yang harus dipelajari sehingga peserta didik dapat memainkan Rebana sebagai pengiring Kesenian Rebana. Setiap pelatih pasti memiliki materi dan cara yang berbeda-beda dalam mengajarkan cara memainkan Rebana, seperti yang dilakukan di kampung Cikambuy Desa Sangkanhurip Kabupaten Bandung rumah Pelatih Rebana adalah rumah yang dipergunakan untuk melatih dan mengajarkan tentang teknik memainkan alat musik Rebana dan lain-lain.

Berdasarkan uraian di atas, khususnya mengenai pelatihan Kesenian Rebana di Cikambuy Desa Sangkanhurip Kecamatan Katapang Kabupaten Bandung yang dilakukan dirumah pelatih kesenian rebana. Peneliti tertarik untuk meneliti pelatihan kesenian rebana yang ada di Cikambuy karena grup tersebut masih eksis dalam segi latihan maupun 
melakukan suatu pertunjukan pada suatu acara tertentu. Peneliti sangat tertarik untuk mengetahui dan menganalisis lebih jauh tentang berbagai hal yang dilakukan pengajar atau pelatih dalam melaksanakan pelatihannya. Ketertarikan peneliti ini akan diwujudkan dalam bentuk kegiatan penelitian dengan mengambil judul : "Pelatihan Kesenian Rebana Grup Al-Maghfiroh Di Cikambuy Desa Sangkanhurip Kecamatan Katapang Kabupaten Bandung"

Dengan harapan hasil temuan penelitian ini dapat menjadi referesnsi pelatihan untuk grup-grup kesenian rebana lainnya, khususnya yang ada di Cikambuy Desa Sangkanhurip Kecamatan Katapang Kabupaten Bandung.

\section{METODE PENELITIAN}

Metode yang digunakan dalam penelitian mengenai pelatihan musik rebana ini adalah metode deskriptif analisis dengan pendekatan kualitatif. Metode ini dianggap tepat digunakan untuk mengkaji tentang proses pelatihan musik rebana yang dilakukan oleh pelatih dan murid dalam kegiatan Pelatihan Kesenian Rebana di Cikambuy Desa Sangkanhurip Kecamatan Katapang Kabupaten Bandung. Pemilihan metode deskriptif yang dilakukan peneliti bukan tanpa alasan, tetapi didasarkan kepada data-data yang akan peneliti kaji dalam penelitian ini. Data-data dalam Pelatihan Kesenian Rebana di Cikambuy Kabupaten Bandung ini bersifat alamiah (naturalist), dimana kegiatan pelatihan ini bukan merupakan rekayasa dari penelitian, tetapi telah berjalan lama sebelum kegiatan penelitian ini dilakukan.

Peneliti melakukan tiga tahap pelatihan yaitu tahap awal, tahap pelaksanaan, dan tahap akhir. Pada tahap awal berisi tentang kegiatan seperti studi pendahuluan dan merumuskan masalah. Tahap pelaksaan berisi tentang kegiatan observasi lanjutan, wawancara, dokumentasi, dokumentasi, dan studi literatur. Tahap akhir berisi tentang pengolahan dan analisis data serta penyusunan laporan.

\section{HASIL DAN PEMBAHASAN}

Pelatih tentunya memiliki materi latihan tersendiri untuk meningkatkan kualitas musik yang diharapkan. Pada proses latihan awal yaitu berdo'a, pemanasan, pelatih mencontohkan atau melakukan demosntrasi, ceramah awal, setelah itu baru pelatih menginstruksikan murid untuk melakukan pemanasan. Latihan pemanasan adalah dasar sebelum memainkan alat musik rebana dengan tujuan untuk melenturkan pergelangan tangan. Berdasarkan hasil wawancara dengan Pak Toni (Maret 2017) bahwa latihan pemanasan ini sangat penting sebelum melakukan latihan dengan teman-teman yang lain, karena dengan tidak didasari cara memegang alat musik rebana yang benar akan berpengaruh untuk kedepannya, karena cara latihan ini bertujuan untuk melenturkan pergelangan tangan tiap individunya.

Setelah latihan kelenturan pergelangan tangan tiap individu melakukan pemanasan dengan pola ritmik yang sudah diberikan pelatih dengan memukul alat musik rebana secara berulang-ulang.

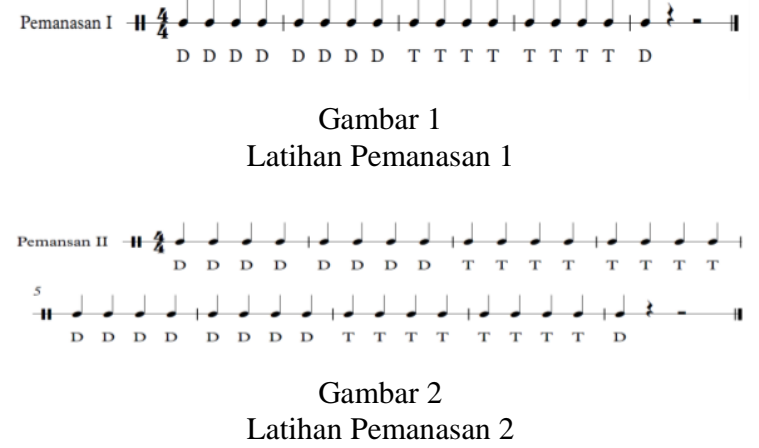

Dari gambar di atas menunjukkan sebuah pola ritmik yang diberikan oleh pelatih pada saat melakukan pemanasan. Ada simbol huruf "D" yang berarti "Dung", "Dung" disini adalah suatu bunyi yang dihasilkan dari bagian tengah badan rebana, dan simbol "T" yang berarti "Tak", "Tak" disini adalah suatu bunyi yang dihasilkan dari bagian pinggir badan rebana. Membunyikannya dengan cara dipukul oleh telapak tangan kebadan tengah dan samping alat musik rebana. Sebelum memulai pemanasan memakai alat musik rebana, pelatih menginstruksikan untuk mengajak murid-murid melakukannya dengan cara bertepuk tangan. Setelah melakukan latihan pemanasan dengan bertepuk tangan, baru dilakukan dengan alat kesenian rebana sebenarnya.

Dalam proses latihan kesenian rebana, tentunya perlu bimbingan yang mendasar dari pelatih mengenai kesenian rebana, karena hal ini bertujuan sebagai patokan untuk murid-murid dalam latihan kesenian rebana. Pada latihan pemanasan ini dibutuhkan metode tutor sebaya untuk mengajarkan murid yang belum mengerti tentang cara melakukan pemanasan awal dan pelatih pun menggunakan metode beo untuk menginstruksikan dan mencotohkan kepada murid-murid yang dia latih atau ajarkan.

Untuk latihan pemanasan vokal, pelatih memberikan latihan pemanasan melenturkan otot rahang, dimainkan dalam tempo yang sama dengan alat musik rebana. Pak Toni mengatakan "pemanasan ini merupakan latihan yang mendasar, untuk muridmurid yang kebagian pada bidang vokal. Latihan pemanasan ini bertujuan supaya murid-murid dapat memahami dasar dari latihan vokal."

Dengan adanya latihan pemanasan ini murid dapat mengatur tempo dan tempo serta melatih posisi tubuh dalam latihan pada saat pemanasan untuk vokal. Latihan ini merupakan latihan yang diterapkan oleh pelatih kesenian rebana di Cikambuy Kabupaten Bandung dalam melakukan latihan rutin kesenian 
rebana. Latihan pemanasan dilakukan bersamaan dengan bimbingan dari pelatih. Pola ritmik dasar untuk pemanasan yang dilakukan bersama-sama adalah sebagai berikut :

Pola Ritmik dasar pada setiap alat musik kesenian rebana digunakan untuk latihan pada grup Al-Maghfiroh di Cikambuy Kabupaten Bandung. Alat musik yang digunakan adalah kecrek, tirintit, tabla, bass, dan hadroh.

\section{Observasi ke-1}

Berdasarkan hasil observasi tanggal 12 Maret 2017, sebelum melakukan kegiatan latihan kesenian rebana, biasanya anak dari Pak Toni mengajak murid-murid yang lain untuk latihan kesenian rebana. Setelah semua kumpul, murid-murid biasanya melakukan do'a bersama sebelum melakukan kegiatan selanjutnya. Setelah itu, muridmurid melakukan pemanasan. Pelatih menginstruksikan kepada anaknya yaitu Rifki untuk memperkenalkan nama-nama alat musik kesenian rebana yang akan dipakai oleh murid-murid yang ada pada grup Al-Maghfiroh. Setelah rifki mengenalkan nama-nama alat kesenian rebana pada temantemannya, Rifki dan teman-temannya mulai menyiapkan alat-alat kesenian rebana untuk memulai latihan kesenian rebana. Setelah mempersiapkan alat musik kesenian rebana, murid-murid mengikuti instruksi yang diberikan oleh pelatih yaitu mulai mengelompokkan diri. Pengelompokkan dibagi menjadi dua kelompok yang terdiri dari kelompok pengiring dan vokal.

Pada pertemuan kali ini, pelatih dan muridmurid akan membahas materi tentang pengenalan pola tabuh dasar alat musik kesenian rebana. Pelatih kemudian memberikan pengarahan kepada muridmurid dan memperkenalkan pola tabuh dasar. Dengan instruksi pelatih, murid-murid diminta untuk membahas materi yang menjadi bahan untuk latihan dipertemuan kali ini yaitu pengenalan pola tabuh dasar alat musik kesenian rebana. Setelah itu pelatih membimbing murid-murid sambil memantau jalannya pelatihan kesenian rebana kali ini. Latihan pola tabuh dasar yang dilakukan oleh murid-murid, bertujuan agar mereka mengetahui dan mengerti tentang pola tabuh dasar dalam bermain alat musik kesenian rebana. Jalannya latihan diawali oleh pelatih yang mencontohkan kepada murid-murid tentang pola tabuh dasar bermain alat musik kesenian rebana, lalu murid mulai mengikuti apa yang diinstruksikan oleh pelatih. Untuk bagian vokal akan dibantu oleh anak pelatih yaitu Rifki. Diawali dengan mendengarkan mp3 contoh lagu yang nantinya akan dipakai dalam latihan kesenian rebana secara berulang-ulang. Hal ini dilakukan agar kelompok vokal dapat mendengarkan iringan dan mendengarkan vokal yang ada pada lagu yang nantinya menjadi bahan untuk latihan dan dilakukan secara berulang-ulang untuk memudahkan murid- murid menghafal lagu yang akan dijadikan bahan untuk latihan.

Berdasarkan hasil wawancara (Maret 2017) pelatih mengatakan bahwa setiap latihan itu harus diawali dengan berdo'a terlebih dahulu sebelum kita melakukan suatu kegiatan. Latihan yang baik adalah latihan yang selalu di awali dengan berdo'a dan melakukan pemanasan secara rutin. Pemanasan dilakukan untuk membiasakan diri sebelum melakukan kegiatan latihan kesenian rebana. Dilakukannya pemanasan ini bertujuan agar kelompok pengiring dan vokal dapat membiasakan diri dan melenturkan pergelangan tangan dan olah vokal murid-muridnya. latihan ini dilakukan berulang-ulang agar murid-murid dapat mengetahui dan memahami pola tabuh dasar pada alat yang akan dimainkan pada lagu yang akan menjadi bahan untuk latihan nantinya.

Setelah hal ini dilakukan dalam waktu beberapa menit sebelum menjelang istirahat dan pulang, biasanya pelatih menginstruksikan kepada seluruh murid untuk melakukan beberapa kali latihan dari mulai pemanasan awal sampai ke pola tabuh khususnya untuk kelompok pengiring, dan untuk bagian vokal pelatih menginstruksikan untuk terus mendengarkan contoh lagu yang diberikan secara berulang-ulang agar dapat menghafalnya. Setelah itu, murid-murid dipersilahkan untuk istirahat oleh pelatih. Setelah istirahat murid-murid diinstruksikan untuk melakukan latihan dengan cara diulang sebanyak satu sampai dua kali putaran. Setelah itu pelatih berbicara kepada murid-murid untuk mengakhiri latihan pada hari ini, dan murid mulai beres-beres dan berdo'a untuk mengakhiri pertemuan pada kegiatan latihan dihari ini.

\section{Observasi ke-2}

Pada pertemuan kali ini, sebelum melakukan proses pelatihan seperti biasa, para murid biasanya mengajak murid-murid lain untuk mulai latihan kesenian rebana. Setelah murid-murid kumpul, mereka melakukan do'a bersama. Setelah itu, muridmurid menyiapkan alat-alat kesenian rebana untuk mulai melakukan pemanasan. Lalu, pelatih menginstruksikan kepada murid-murid untuk mulai mengelompokkan diri, yaitu kelompok pengiring dan vokal. Pembahasan materi dipertemuan kali ini adalah membahas materi lagu Busrolana dan mulai memperdalam materi lagu tersebut.

Pada pertemuan kali ini, Pelatih menginstruksikan kelompok pengiring untuk melakukan pemanasan tetapi tidak menggunakan alat musik kesenian rebana, melainkan menggunakan tangan dengan cara ditepuk. Pelatih menginstruksikan agar murid-murid mendengarkan pola tabuh yang ada pada lagu Busrolana. Untuk kelompok pengiring latihan dilakukan dengan cara mendengarkan lagu dari awal hingga akhir lagu. Mendengarkan dan menghafal pola tabuhnya tidak langsung dari awal lagu hingga akhir lagu, tetapi ada 
tahapannya yang harus dilakukan yaitu, agar mempermudah murid-murid untuk menghafal lagu tersebut. Dengan bimbingan pelatih, murid-murid pada kelompok pengiring mulai mendengarkan lagu Busrolana perbagian lagu, mereka pun tidak lupa pula mendengarkan pola tabuh yang ada pada lagu tersebut. Hal ini dilakukan dengan cara berulangulang agar murid-murid dapat menghafal lagu dan pola tabuh yang ada pada lagu tersebut.

Setelah melakukan pemanasan, Pak Toni Memberikan arahan kepada murid-muridnya untuk mulai masuk ke materi yang akan dibahas yaitu lagu busronala. Pada Bagian Awal Lagu Busrolana bar 1 dan 2, alat musik yang dimainkan dimulai dari Bass, Keckrek, dan Tabla, sedangkan Hadroh dan Tirintit masih diam. Pada bar ke-3 alat musik Hadroh dan tirintit mulai dimainkan. Pada bar ke-3 ada perubahan pola tabuh untuk semua alat musik yang digunakan, maka dari itu pelatih menginstruksikan murid untuk mendengarkan bagian lagu yang pola tabuhnya berbeda dengan bagian awal, hal ini bertujuan untuk melancarkan bagian yang agak sulit khususnya untuk pola tabuh alat musik pada lagu busrolana. Untuk membiasakan pola tabuh yang murid-murid lakukan pada bagian lagu yang tingkat pola tabuhnya lebih rumit dari yang sebelumnya, dilakukan dengan cara mendengarkan dan mempraktikan secara berulangulang.

Selanjutnya, pada bar ke-3 alat musik hadroh dan tirintit mulai dimainkan. Fungsi dari kedua alat musik ini saling mengisi satu sama lain. Pak Toni mengajarkan perbagian dari tiap alat yang digunakan pada pelatihan kesenian rebana ini khususnya pada lagu Busrolana. Pak Toni mengajarkan murid-muridnya dengan cara metode ceramah dan menjelaskan pola tabuh untuk setiap alat yang digunakan pada pelatihan kesenian rebana ini. Pola tabuh semua alat dari bar ke-3 sampai dengan bar 10 masih tetap sama, hal tersebut dilakukan oleh para murid dengan cara mendengarkan lagu busrolana dan melatih pola tabuhnya secara berulangulang.

Setelah Pak Toni mengajarkan pola tabuh kepada setiap murid, pelatih menginstruksikan kepada murid untuk mendengarkan lagu busrolana secara berulang-ulang dan murid-murid pun sambil mendengarkan instruksi dari Pak Toni kapan harus berganti pola tabuh pada bagian lagu Busrolana. Pada bar 10 ada perubahan pola menjadi lebih simple dari sebelumnya, karena fungsi pada bar 10 ini adalah sebagai jembatan untuk masuk ke bar selanjutnya. Pada bar 11 pola tabuh semua alat musik yang digunakan pada pelatihan kesenian rebana ini mulai agak rumit dari bar sebelumnya. Pak Toni memberi arahan kepada murid-muridnya agar berhati-hati pada bar 11 sampai dengan selanjutnya karena pola tabuhnya berbeda dengan pola tabuh di bar sebelumnya. Pak Toni pun selalu mengingatkan kepada murid-muridnya agar mendengarkan lagi lagu busrolana secara berulang-ulang dan mempraktikan apa yang sudah diajarkan oleh pelatih kesenian rebana.

Setelah latihan ini dilakukan secara berulang-ulang, murid mulai terbiasa dengan apa yang sudah mereka dengar dan latih. Pada bar 11 pola tabuh alat musiknya tetap sama sampai bar 17. Pada bar 18 pola tabuh nya sama seperti dibar 10 , karena fungsi di bar 18 masih sama dengan bar 10 yaitu sebagai jembatan untuk masuk ke bar selanjutnya. Pada bar 19 sampai bar 25 pola tabuhnya masih tetap sama. Pada bar 26 pola tabuhnya masih sama dengan bar 10 dan 18, fungsinya sebagai jembatan untuk masuk ke bar selanjutnya.

Pada Bar 27 pola tabuh alat musik kesenian rebana yang digunakan pada grup Al-Maghfiroh sama seperti bar 11. Pak Toni terus memberikan arahan kepada murid-muridnya agar terus melatih dan mendengarkan bagian lagu yang pola tabuhnya agak rumit dengan menggunakan metode beo atau ceramah. Pelatih pun selalu melihat keseluruhan murid khususnya yang memegang alat musik kesenian rebana dan selalu membantu murid yang kesulitan. Pak Toni melakukan hal tersebut karena melihat kondisi murid-murid yang tidak semua, cepat dalam melatih pola tabuh pada bar 11 dan 27 khususnya. Setelah melihat keseluruhan siswa, masih banyak murid-murid yang kesulitan dalam menghafal pola tabuh alat musik kesenian rebana khususnya pada bar 11, 27 dan bar lain. Setelah Pak Toni melihat kondisi murid-murid, Pak Toni memberi arahan dan mencontohkan dengan mengimitisikan lagu busrolana dengan menggunakan pola tabuh yang lebih sederhana, dibandingkan lagu busrolana yang ada pada mp3 khususnya yang mereka dengar. Hal ini dilakukan oleh pelatih agar mereka lebih mudah memahami pola tabuh pada lagu busrolana secara bertahap.

Setelah Pak Toni melatih kelompok pengiring, Pak Toni mulai menginstruksikan Rifki (anak dari Pak Toni) untuk membantu melatih kelompok vokal, latihannya dilakukan bersamasama. Sebelum melakukan latihan vokal, Rifki membantu teman-teman yang lain untuk melakukan pemasan terlebih dahulu. Pemanasan dipandu oleh Rifki, pemanasan vokal yang dilakukan adalah dengan cara melenturkan rahang, melatih artikulasi (A,I,U,E,O), lalu melatih pernafasan, dan memperhatikan sikap badan pada saat latihan berlangsung. Setelah melakukan pemanasan, latihan dilakukan dengan cara mendengarkan lagu Busrolana yang bertujuan untuk menghafalkan bagian-bagian lagu dan liriknya. Cara yang mempermudah kelompok vokal untuk menghafal lagu bukan hanya sekedar mendengarkan saja, melainkan murid-murid menulis lirik lagunya dan cara menghafalnya didengarkan sambil membaca lirik yang sudah mereka tulis. 
Pak Toni dan Rifki melihat bahwa kelompok vokal mendapati kesulitan pada range nada yang tinggi dan rendah. Pak Toni menginstruksikan muridmurid bernyanyinya dengan memperhatikan posisi tubuh untuk tidak membungkuk atau harus tegak, karena hal tersebut menghambat pernafasan khususnya pada kelompok vokal. Alhasil setelah memberikan saran kepada murid, sedikit-sedikit kelompok vokal mulai terbiasa. Setelah kedua kelompok berlatih dalam beberapa menit, pelatih menginstruksikan kepada murid-murid agar kedua kelompok mencoba latihan gabungan.

Menurut hasil wawancara Pak Toni mengatakan bahwa "Hal ini bertujuan, untuk melihat kekurangan yang ada pada kedua kelompok". Ternyata setelah dilihat, bahwa murid-murid masih banyak kekurangan dan harus mulai latihan perkelompok lagi. Sebelum memulai latihan perkelompok, pelatih menginstruksikan murid-murid untuk istirahat terlebih dahulu. Setelah beristirahat, murid-murid mulai melakukan latihan perkelompok lagi secara berulang-ulang. Beberapa menit telah berlangsung dan pak Toni menginstruksikan muridmurid untuk mencoba latihan gabungan lagi dengan dua kali pengulangan. Setelah itu murid-murid beresberes lalu berdo'a untuk mengahiri pertemuan pada hari ini.

\section{Observasi ke-3}

Berdasarkan hasil observasi tanggal 18 Maret 2017, sebelum melakukan kegiatan latihan kesenian rebana, biasanya anak dari Pak Toni mengajak murid-murid yang lain untuk latihan kesenian rebana di kediaman Pak Toni. Setelah semua kumpul, murid-murid biasanya melakukan do'a bersama sebelum melakukan kegiatan selanjutnya. Setelah itu, murid-murid melakukan pemanasan seperti biasa. Kemudian, pelatih membahas materi pelatihan kesenian rebana pada pertemuan sebelumnya.

Pertemuan kali ini Grup Al-Maghfiroh akan melancarkan materi pelatihan kesenian rebana pada lagu Busrolana. Setelah melakukan kegiatan pelatihan kesenian rebana dipertemuan sebelumnya, pelatih mulai menginstruksikan murid-murid untuk mengulang materi sebelumnya dari awal lagu sampai akhir lagu dengan pola tabuh yang sudah dilatih pada pertemuan sebelumnya khususnya untuk kelompok pengiring, dan pelatih pun menginstruksikan untuk kelompok vokal juga agar memulai latihan gabungan dengan kelompok pengiring. Hal ini dilakukan secara bersamaan dan dilakukan secara berulang-ulang sampai murid-murid mulai terbiasa dengan latihan kesenian rebana ini pada lagu Busrolana.

Setelah pelatih melihat bahwa sekiranya murid-murid sudah aman dalam pelatihan kesenian rebana pada lagu Busrolana, pelatih mulai menginstruksikan murid-murid untuk beristirahat sejenak. Setelah istirahat dan sebelum mengakhiri proses pelatihan hari ini, pelatih mulai menginstruksikan murid-murid untuk beres-beres. Setelah semuanya selesai, pelatih mulai melakukan kegiatan evaluasi pelatihan pada hari ini khususnya untuk seluruh murid-murid.

Diakhir kegiatan setelah beberapa kali pertemuan untuk latihan kesenian rebana, pelatih menjelaskan bahwa "dalam beberapa kali pertemuan latihan ini bertujuan agar kalian(murid-murid) dapat mengenal sedikitnya tentang kesenian rebana." Pelatih pun mulai menutup kegiatan pada pertemuan hari ini, dan murid-murid pun mulai berdo'a untuk mengakhiri kegiatan pelatihan kesenian rebana hari ini.

Untuk mengetahui hasil latihan, diperlukan adanya kegiatan evaluasi dalam kegiatan latihan ini. Teknik evaluasi pada pelatihan kesenian rebana pada Grup Al-Maghfiroh di Cikambuy Kabupaten Bandung adalah dengan melakukan semacam test kepada murid-murid seperti menginstruksikan muridmurid melakukan kegiatan pelatihan kesenian rebana setelah melakukan pelatihan sebelumnya. Dengan melakukan semacam tes ini bertujuan untuk mengetahui pencapaian murid-murid dalam menguasai materi yang dipelajari oleh pelatih dan murid-murid. Kegiatan evaluasi ini tidak dilakukan secara terjadwal, melainkan dilakukan kapan saja selama proses latihan kesenian rebana berlangsung.

Setelah melakukan evaluasi ternyata, dapat dinilai bahwa tidak semua murid memiliki kemampuan untuk menangkap suatu materi pelatihan yang diberikan oleh pelatih, akan tetapi ada kelompok siswa yang belum cepat dalam menguasai materi latihan dan ada juga murid yang cepat dalam menangkap materi yang telah diberikan oleh pelatih. Untuk membantu murid yang belum bisa menangkap materi yang diberikan oleh pelatih pada saat latihan, pelatih memberikan motivasi kepada murid serta menganjurkan untuk latihan lagi dengan murid-murid yang sudah lebih bisa menangkap materi yang telah diberikan diluar jadwal latihan rutin yang tidak mengganggu jam sekolah yaitu hari libur.

Hal ini cukup membatu pelatih dalam mencapai tujuan pelatihan kesenian rebana khususnya yang diinginkan oleh pelatih serta pertimbangan dalam melakukan latihan agar memperlancar proses latihan kesenian rebana pada grup Al-Maghfiroh di Cikambuy Desa Sangkanhurip Kecamatan Katapang Kabupaten Bandung.

Pelatihan merupakan suatu proses yang terdiri dari serangkaian kegiatan yang terencana dan terarah. Penggunaan metode dalam pelatihan adalah merupakan teknik yang digunakan pelatih untuk menyampaikan suatu materi yang ditujukan kepada murid-murid agar dapat mengerti dan memahami materi yang diberikan oleh pelatih serta agar dapat berupaya untuk mencapai suatu tujuan dalam suatu pelatihan kesenian rebana. Metode yang digunakan dalam pelatihan juga berperan sebagai salahsatu cara untuk meningkatkan kemampuan tiap individunya 
untuk mencapai suatu tujuan dari pelatihan kesenian rebana. Seperti yang dikemukakan oleh Sudjana (2007) bahwa : "tujuan utama pelatihan adalah memberikan pengaruh bagi peningkatan kemampuan dan kualitas peserta, pembelajaran orang lain, dan konstribusinya bagi membangun masyarakat". Mengacu pada penjelasan tersebut bahwa pelatihan kesenian rebana pada grup Al-Maghfiroh tentunya dilakukan oleh pelatih untuk mencapai tujuan pelatihan yang diharapkan.

Berdasarkan pengamatan peneliti, untuk mencapai suatu tujuan pelatihan metode yang diterapkan pada kegiatan pelatihan kesenian rebana di Cikambuy Kabupaten Bandung oleh pelatih sudah cukup baik, karena pelatih menggunakan metode ortodoks dengan cara dibeo untuk mencapai tujuan pelatihan yang diharapkan. Menurut KBBI : "Ortodoks/or-to-doks/ 1. Berpegang teguh pada peraturan dan ajaran resmi, misalnya dalam agama; 2 . Kolot; berpandangan kuno.” Metode yang pakai oleh pelatih adalah metode ortodoks yang digunakan untuk melatih murid-murid pada grup Al-Maghfiroh. Cara yang dilakukan oleh pelatih kesenian rebana memakai metode ortodoks sangat efektif ketika pelatihan kesenian rebana belangsung. Berdasarkan hasil pengamatan peneliti, metode ortodoks yang digunakan oleh pelatih mirip dengan metode beo atau menggunakan cara langsung. Cara langsung yang dimaksud adalah peserta didik mengikuti apa yang pelatih ajarkan atau mengikuti apa yang dicontohkan oleh pelatih secara langsung.

Materi pelajaran dalam pelatihan sangat diperlukan, karena dengan adanya materi pelajaran dalam pelatihan seorang pelatih dapat menentukan menentukan materi yang akan di ajarkan kepada murid-muridnya. Seperti yang dikatakan oleh Masjoko (2015, hlm 6) bahwa materi pelajaran adalah sejumlah materi yang akan disampaikan oleh guru kepada peserta didik. Dalam menyusun materi ajar, guru harus memahami apakah materi yang akan disampaikan berupa konsef, pengetahuan factual atau pengetahuan yang berhubungan dengan keterampilan, supaya guru lebih mudah dalam menentukan metode yang akan digunakan.

Sejalan dengan pendapat yang dikemukakan oleh Masjoko (2015, hlm 6) bahwa, sesudah menentukan materi yang digunakan untuk pelatihan kesenian rebana di Cikambuy Kabupaten Bandung. Sebelum melakukan pelatihan kesenian rebana Pak Toni menyiapkan materi yang akan diajarkan kepada murid, setelah menyiapkan materi yang akan diajarkan kepada murid, Pak Toni menentukan metode yang dipakai pada saat pelatihan kesenian rebana untuk membantu dan mempermudah dalam proses pelatihan kesenian rebana grup Al-maghfiroh di Cikambuy Kabupaten Bandung.

Tujuan dilakukannya persiapan sebelum melakukan latihan kesenian rebana adalah untuk membiasakan dan mempersiapkan segala materi untuk dibahas pada pertemuan tersebut khususnya untuk pelatih. Tidak menutup kemungkinan bahwa murid pun selalu diingatkan untuk melakukan pemanasan sebelum melakukan pelatihan agar terbiasa pada saat memainkan karya yang akan dibahas pada pertemuan tersebut. Materi yang akan dibahas dan dilatih pada pertemuan tersebut adalah lagu Busrolana.

Materi Busrolana dilatih karena kesepakatan dari pelatih dan murid. Setelah proses pemanasan dilakukan, banyak kesulitan yang dihadapi. Kesulitan tersebut terdapat pada setiap murid, karena dalam kemampuan setiap murid berbeda. Ada yang cepat dalam menangkap materi yang disampaikan oleh pelatih, atau sebaliknya. Hal ini adalah tugas dari seorang Pak Toni untuk membantu dan membimbing murid dalam suatu proses latihan yang dilakukan oleh grup Al-Maghfiroh.

Untuk melihat hasil pencapaian tujuan penerapan metode pelatihan diperlukan kegiatan evaluasi. Seperti yang dikemukakan oleh Arikunto (2012:325) "evaluasi program adalah suatu rangkaian kegiatan yang dilakukan dengan sengaja untuk melihat tingkat keberhasilan program". Dengan kata lain kegiatan evaluasi dilakukan untuk melihat tingkat kompetensi siswa yang dicapai dalam proses pelatihan. Dilihat dari proses pelatihan yang dilakukan oleh pelatih tentunya masih perlu dibenahi. Metode ortodoks yang digunakan pelatih untuk melatih kesenian rebana di Cikambuy Kabupaten Bandung memang sudah cukup baik, akan tetapi masih belum sempurna karena dilihat pada saat observasi ada kecenderungan yang timbul dari segi negatifnya.

Dengan diterapkannya metode ortodoks terus menerus oleh pelatih tentu memiliki kelemahan yang berdampak pada murid-murid yang dilatih oleh pelatih, kegiatan pelatihannya bersifat menerima dan menghafal materi yang telah diberikan dan dicontohkan oleh pelatih, dan pada saat anak dari pelatih membantu dalam proses pelatihan kesenian rebana untuk melatih murid pada kelompok vokal khususnya ada ketergantungan kepada anak dari pelatih yang menjadikan suasana pelatihan kesenian rebana menjadi tidak kondusif, bahkan sebagai anak dari pelatih yang membantu jalannya pelatihan membuat murid-murid yang dilatihnya menjadi tidak kondusif karena merasa bahwa anak dari pelatih tidak berbeda jauh dengan umur anak pelatih tersebut.

Dalam kegiatan pelatihan kesenian rebana yang dilakukan di Cikambuy Kabupaten bandung, evaluasi paling mendasar adalah untuk semua kelompok dalam penguasaan pembahasan materi lagu yang diberikan pelatih. dilihat dari hasil observasi, evaluasi secara menyeluruh tidak tanpa mempertimbangkan evaluasi secara individu.

Adapun faktor-faktor yang mempengaruhi proses pelatihan dalam penelitian ini adalah faktor penghambat dan penunjang. Faktor penghambat 
diantaranya adalah: 1) pada saat pelatihan muridmurid sulit untuk berkumpul; 2) kondisi psikologis anak pada usia dini masih labil dan masih mencari jati diri; 3) pada saat pelatihan berlangsung, dan pelatih sedang keluar dari tempat pelatihan, kondisi murid menjadi tidak kondusif; 4) murid-murid kurang percaya diri; 5) tidak semua murid dapat memahami dengan cepat khususnya materi yang disampaikan oleh Pak Toni (pelatih). Sedangkan faktor penunjang dalam penelitian ini adalah: 1) adanya bakat alami yang dimiliki oleh pelatih; 2) profesi pelatih lainnya seperti guru mengaji, kepala dusun, tokoh masyarakat; 3) adanya dukungan dari keluaga; 4) adanya motivasi untuk mengikuti pertunjukkan.

\section{KESIMPULAN}

Berdasarkan temuan penelitian yang dibahas tentang pelatihan kesenian rebana grup Al-Maghfiroh di Cikambuy Desa Sangkanhurip Kecamatan Kabupaten Bandung, yang terfokus pada proses pembelajaran yang terjadi dalam penerapan pelatihan kesenian rebana, maka pada bab ini peneliti mengambil kesimpulan dari hasil penelitian, yakni:

1. Proses pelatihan kesenian rebana di Cikambuy Kabupaten Bandung merupakan proses latihan yang dilakukan secara berkelompok dan dilakukan secara bersamaan. Pelatihan dibagi menjadi dua kelompok. Kelompok pertama adalah kelompok pengiring, dan kelompok ke dua adalah kelompok vokal. Kelompok pengiring dibimbing oleh Pak Toni Syahroni, dan kelompok vokal dibantu oleh anaknya sendiri yaitu Rifki untuk membantu membimbing kelompok vokal. Metode yang digunakan oleh pelatih untuk melatih kesenian rebana di Cikambuy Kabupaten Bandung adalah metode ortodoks. Metode ortodoks itu adalah metode yang digunakan pada jaman dulu atau bisa disebut sebagai metode yang kuno. Metode ini sangat membantu pada saat pelatihan kesenian rebana, khususnya untuk mencapai suatu tujuan yang diharapkan dalam pelatihan kesenian rebana di Cikambuy Kabupaten Bandung. Beberapa tahapan yang dalam proses pelatihannya yaitu mengenai alat musik kesenian rebana, mengenal sedikitnya tentang alat kesenian rebana, posisi dan cara memainkan alat musik kesenian rebana, cara memainkan alat musik kesenian rebana, belajar mengikuti apa yang dicontohkan oleh pelatih, dan pembahasan lagu. Materi pelatihan yang diajarkan secara umum merupakan materi dasar untuk pelatihan kesenian rebana. Dalam mempersiapkan materi pelatihan, pelatih tidak mengacu pada kurikulum, akan tetapi pelatih dan murid bebas dalam menentukan sebuah materi untuk menentukan materi pelatihan pada saat itu. Proses kegiatan sebelum masuk pada tahap latihan, biasanya pelatih dan murid-murid melakukan kegiatan rutin terebih dahulu, yaitu mengajak anak-anak untuk latihan kesenian rebana, berdo'a sebelum mulai latihan, menentukan materi yang akan dilatih pada pertemuan tersebut, pemanasan, pengelompokkan dan mulai untuk latihan. Pemanasan dilakukan secara bersama-sama, serta diperhatikan pula posisi tubuh dalam memainkan alat musik dan vokal, belajar menghafal perbagian lagu, dan pembahasan lagu. Cara pemanasan sebelum memakai alat untuk kelompok pengiring dilakukan dengan cara bertepuk tangan dan untuk vokal melatih rahang, nafas, dan artikulasi. Materi lagu yang ditentukan bersama-sama untuk pelatihan kesenian rebana merupakan lagu yang pada umumnya sering dipakai dalam pelatihan kesenian rebana oleh grup-grup kesenian rebana yang ada di Indonesia.

2. Dalam kegiatan kesenian rebana yang dilakukan di Cikambuy Kabupaten Bandung, evaluasi paling mendasar adalah untuk semua kelompok alat musik. Dilihat dari observasi, evaluasi yang dilakukan oleh pelatih hanya mengevaluasi secara berkelompok tidak mempertimbangkan evaluasi individu murid-muridnya.

Berikut ini beberapa rekomendasi atau saran yang diharapkan dapat memberikan masukan yang bermanfaat:

\section{Kepada Pelatih}

Dalam proses pelatihan seharusnya tidak memakai satu metode pelatihan melainkan adanya kolaborasi dengan metode-metode yang lain sehingga dengan adanya kolaborasi, metode pelatihan lainnya akan lebih baik. Dengan adanya kolaborasi tersebut, kedekatan seorang pelatih dengan siswa akan menjadi lebih akrab, serta kecanggungan siswa kepada pelatih akan sedikit hilang. Dalam hal ini, pelatih tentunya membimbing siswa secara baik dengan cara dibimbing per individunya, karena menurut pak toni murid-murid yang dia ajarkan sudah dianggap sebagai keluarga. Dalam proses evaluasi, pelatih melihat perkembangan tiap-tiap siswanya apalagi dalam hal penangkapan materi tiap individunya. Hal ini pun dilakukan pelatih agar dapat mengetahui potensi sejauh mana kemampuan tiap individunya pada saat pelatihan kesenian ini berlangsung khususnya dalam proses pembelajaran dan pelatihan kesenian rebana pada grup Al-Maghfiroh di Cikambuy Kabupaten Bandung.

\section{Kepada Murid}

Murid yang berlatih kesenian rebana di Cikambuy Kabupaten Bandung diharapkan dapat lebih giat dalam pelatihan kesenian rebana. Disarankan juga agar murid-murid untuk tidak malu mempertahankan tradisi yang ada di Indonesia dan kalian harus bangga dengan apa yang kalian lakukan 
apalagi kesenian rebana ini mempunyai tujuan khusus untuk menyi'arkan agama melalui kesenian rebana.

\section{DAFTAR PUSTAKA}

Arikunto, Suharsini. (2012). Dasar-dasar Evaluasi Pendidikan "(Edisi Revisi)". Cet. IX; Jakarta : Bumi Aksara.

Dahar, Ratna Wilis. 2011. Teori-Teori Belajar \& Pembelajaran. Bandung : PT Gelora Aksara Pratama.

Devindrin Kusuma, Putu Sandra. (2014). Pelatihan Seni Tabuh Gamelan Goong Kebyar Di Pura Wira Satya Dharma Ujung Berung Bandung. Bandung : Skripsi Departemen Pendidikan Seni Musik FPSD UPI.

Guritno, Sri dan Manullang, Binsar. (1998-1999). Budaya Masyarakat Di Lingkungan Kawasan Industri Rotan Desa Tegal Wangi, Kabupaten Cirebon, Provinsi Jawa Barat. Jakarta : CV. BUPARA.

Instruksi Presiden. (1974). Undang-Undang Republik Indonesia No 15 Tahun 1974 tentang Pelaksanaan Keputusan Presiden Nomor 34 Tahun 1972. Jakarta. [Online]. Diakses dari

https://peraturan.bkpm.go.id/jdih/userfiles /batang/InPres_15_1974.pdf

Joko. (2015). Metode pembelajaran. Jakarta: Universitas Negeri Jakarta.

Kamil, Mustofa. (2010). Model Pendidikan Dan Pelatihan : Konsep Dan Aplikasi. Bandung: Alfabeta.

Kartika, Ikka. (2011). Mengelola Pelatihan Partisipatif. Bandung : Alfabeta.

Komalawati, I. (2016). Pembelajaran Kesenian Rebana Di MTS Rohmah Kabupaten Garut. (Skripsi). Bandung: Departemen Pendidikan Seni Musik FPSD UPI.

Kubarsah, Ubun. (1994). Mengenal Alat-alat Kesenian Daerah Jawa Barat. Bandung : Beringin Sakti.

Maulida, Diana. 2016. Pertunjukan Seni Terebang Gebes Grup Candralijaya Pada Acara Hajat Lembur Di Kampung Cirangkong Desa Cikeusal Kecamatan Tanjungjaya Kabupaten Tasikmalaya. Bandung : Skripsi Departemen Pendidikan Seni Musik FPSD UPI.

Mukhtar dan Martinis Yasmin. 2001. Metode pembelajar yang berhasil. Jakarta : CV Sasama Mitra Suksesa.
Perkasa, Rian. 2017. Pelatihan Drum Band Dengan Metode Tutor Sebaya Di SMPN 3 Lembang. Bandung : Skripsi Departemen Pendidikan Seni Musik FPSD UPI.

Rosset, Allison \& W. Arwady, Joseph. (1987). Training Needs Assesment. Educational Technology Publications Englewood Cliffs, New Jersey 07632

Rusyana, Yus. (2000). Tujuan Pendidikan Seni. Gelar: Jurnal Ilmu dan Seni STSI Surakarta: STSI Press.

Sagala, Syaiful. (2004). Konsep dan Makna Pembelajaran. Bandung : Alfabeta.

Sastradipoera. 2006. Pengembangan dan Pelatihan. Bandung : Kappasigma

Satori dan Komariah. 2014. Metodologi Penelitian Kualitatif. Bandung: Alfabeta.

Sedyawati, Edi. (2002). Budaya Indonesia: Kajian Arkeologi, Seni, dan Sejarah. Jakarta : PT Rajagrafindo Persada

Sinaga, S. S. (2006). Fungsi dan Ciri Kesenian Rebana di Pantura Jawa Tengah. (Jurnal Pengetahuan dan Pemikiran Seni). 8. (3) [Online] Tersedia: http//journal.unnes.ac.id/nju/index.php/ha rmonia/article/view/736/665 [5 Mei 2013].

Sudjana, Djudju. (2007). Sistem Dan Manajemen Pelatihan: Teori Dan Aplikasi. Bandung : Falah Production.

Sugiyono, (2008). Metode Penelitian Kuantitatif Kualitatif dan $R \& D$. Bandung : Alfabeta.

Sugiyono. 2014. Memahami Penelitian Kualitatif. Bandung : Alfabeta

Suyono dan Haryanto. 2011. Belajar dan Pembelajaran. Bandung : PT. Remaja Rosdakarya Offset.

Soepandi, Atik. Atmadibrata, Enoch (1977). Khasanah Kesenian Daerah Jawa Barat. Bandung : Pelita Masa.

www.inigresik.com/2014/06/terbang-atau-rebanaalat-musik.html?m=1.di akses 18 Agustus $\underline{2017}$

Yulia, S. (2016). Pembelajaran Rebana Qasidah Di Baituttarbiyah (Rumah Pendidikan) Abu Zacky Al-Zam Zamy Pangandaran. Bandung : Skripsi Departemen Pendidikan Seni Musik FPSD UPI.

Yuliawati, E. (2017). Pelatihan Angklung Diatonis Pada Ekstrakurikuler Musik Di MTs Negeri 1 Sumedang. Bandung : Skripsi Departemen Pendidikan Seni Musik FPSD UPI. 
Mochammad Septa Satria Saputra / DESKOVI : Art and Design Journal, Vol. 3, No.1, Juni 2020, 49-58

(Halaman ini sengaja dikosongkan) 